\title{
ЛЕКСИКОГРАФСКА ОБРАДА АНАТОМСКЕ ТЕРМИНОЛОГИЈЕ У ДЕЛУ „КРАТКО СОЧИҢЕНИЈЕ ИЛИ НАУКА О ЧОВЕКУ” ПЕТРА РАДОВАНОВИЋА
}

\begin{abstract}
САЖЕТАК
У раду је анализиран терминолошки систем предстандардне епохе српског језика из домена анатомије у делу Кратко сочињеније антропологије или Наука о човеку Петра Радовановића (1844). Дати су основни подаци о аутору, терминологији и теоријско-методолошким оквирима истраживања, а потом је ексцерпирана грађа дата у виду речника. Истраживање се врши ради упоређивања односа између анализираног терминолошког система из области анатомије и одговарајућег регистра савременог српског језика.
\end{abstract}

КЉУЧНЕ РЕЧИ: терминолошки систем, терминологија, анатомија, 19. век.

\section{1. Предмет, задаци и корпус истраживања}

Предмет овог рада је анализа лексичког система из домена анатомске терминологије $\mathrm{e}^{1}$ у делу Кратко сочињеније антропологије или Наука о човеку Петра Радовановића (1844). Основни задатак овог истраживања је издвајање термина из области анатомије у виду речника. Текст је писан доситејевским ${ }^{2}$

${ }^{1}$ Под терминологијом се подразумева систем термина, речи које се употребљавају у науци да означе одређени појам одговарајуће научне, техничке и уметничке области (Šipka 1998: 126; Михаљевић 1997: 7; Драгићевић 2007: 20). Предмет терминологије као науке језичке је врсте, али је истовремено вишедисциплинаран: припада лингвистици и њеним бројним гранама и правцима исто колико и логици, онтологији, информатици, а теорија помиње и класологију, одговорну вештину уређивања већ постојећег устројства (Винавер 1996: 21). Терминолошке јединице припадају и општем лексичком фонду и специјалном, специфичном, стручном и научном. Специфичност је њихова у типу семантичког садржаја који номинују (Гортан-Премк 1991: 49).

${ }^{2}$ Под овим типом књижевног језика подразумева се језик који је у својој основи био српски с одређеним елементима, углавном из периферне језичке структуре (пре свега из лексичког система), који су били рускословенске провенијенције - тзв. славенизми. 
типом језика, традиционалном нереформисаном ћирилицом грађанског типа. Издвојена су 242 термина, који се јављају у скоро једнаком броју у виду једночланих и вишечланих терминолошких јединица.

\section{2. Лексикографска обрада}

У раду је ексцерпирана грађа дата у виду речника, који је заснован на анатомској предстандардној терминологији из дела Петра Радовановића Кратко сочињеније антропологије или Наука о човеку. Одреднице су у овом речнику транскрибоване и уређене према азбуци стандардног српског језика. Неопходно је било извршити транскрипцију одредница да би се олакшало његово праћење, те би се тиме речник прилагодио ширем кругу читалачке публике која је заинтересована за ову тематику (Бјелаковић 2017: 198).

Одреднице су транскрибоване савременом српском ћирилицом, према начелима Правописа српског језика (Пешикан, Јерковић и Пижурица 2010). У следећој табели приказане су гласовне вредности графема, односно графемских група.

\begin{tabular}{|c|c|}
\hline Графема/графемска група & Гласовна вредност \\
\hline$<\mathrm{b}>$ & [e]: бъла џигерица \\
\hline <ль, нь> на крају речи или слога & {$[1, n]$ : дольной жучной бешики, наковань } \\
\hline <я> на почетку слога или речи & [ја]: Адамову ябуку \\
\hline <ня, ля> & [la, na]: ртенячне зглавкове, грклянъ \\
\hline <ю> на почетку слога & [ju]: костію \\
\hline $\begin{array}{l}<\mathrm{e}>\text { на почетку слога или речи и иза } \\
\text { вокала }\end{array}$ & [je]: извіенъ ходникъ, езычнной кости \\
\hline$<\mathrm{i}>$ & [i]: біюће жиле \\
\hline$<\mathrm{b}>$ & [i]: зглавковыма \\
\hline$<\breve{и}>$ & [j]: езычнной кости \\
\hline 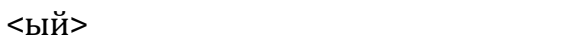 & [i]: малый мозакъ \\
\hline$<\mathrm{i} \breve{и}>$ & [i]: псећій зуб \\
\hline$<\mathrm{b}, \mathrm{b}>$ & $\begin{array}{l}\text { без словне вредности, маркирају крај речи } \\
\text { или слога: жучъ, кичмену масть }\end{array}$ \\
\hline
\end{tabular}

Статус одреднице у речнику добили су и једночлани (нпр. брада, мозак) и вишечлани термини. Речнички чланак у овом раду подразумева: 1.

Доситеј Обрадовић се сматра родоначелником овог језика, а следили су га и многи војвођански писци током прве половине 19. века (Суботић 2004: 164). 
одредницу (транскрибовану и маркирану болдом), 2. граматичку информацију (обележје рода уз именицу - м, ж, с), 3. регистровану форму у оригиналу (у угластим ортографским заградама), 4. дефиницију у курзиву, ${ }^{3}$ 5. потврду са (ширим) контекстом у којем је пример забележен, с податком о иницијалима аутора, годином и одговарајућом страницом извора.

3 Након дефиниције, наведен је и латински назив органа, уколико је пронађен. 


\section{4. Речник}

A

адамова јабука ж <Адамову ябуку> испупчена хрскавица у грлу над улазом у душник, код мушкариа, адамова јабучища (лат. potut Adami). Овай каналъ саставльнъ е понайвыше изъ р'скавица, и горе има видиму малу гуку (тако названу Адамову ябуку), коя е кодъ мушкогъ пола яча и већа, него кодъ женскогъ (ПМ 1844: 12).

\section{Б}

бала ж <балама> слуз у носној дупљи која одржава њену влажност и штити je од спољашњих утицаја. - Кожа задржава се у влаги нькимъ балама, да бы се летеће (испараеме) части разны тьлеса, лакше ухватити, ньіово голицанъ ако бы врло яко было, умърити, а и самымъ нервыма сохраненіе дати могло (ПМ 1844: 18).

балава кожа ж <балава кожа> кожа на унутрашњој страни неких шупљих органа коју покрива слуз, слузокожа. Носъ, орудіе обонянія, (мирисаня) обложенъ е изъ нутра горе са сунђеру подобномъ шупльикастомъ кожомъ. Она се балава кожа (Schleimhaut) зове, и да бы млого поверхности у маломъ простору заузела, извіена е преко разны папирно-танки коштица (ПМ 1844: 18).

балава кожица ж <балавой кожицы> танак слој слузокоже. - Кончићи нерва често се дъле, но опетъ се еданъ съ другимъ союжаваю, и образую дебело оддвоеніе или клупче нерва, кое се са основнымъ частима мозга прилично соглашаваю, и многе крвне сосуде содржаваю, или се у замршеным свезама саставляю, кое се плетиво нерва зове, и распростиру се такође у найманъ части тьла, па или се у финой балавой кожицы, или у врло нЊжной брадавичицы окончаваю (ПМ 1844: 17).

балави прозрачни завитак м <балавый прозрачный завитакъ> танак, слузави слој који прекрива површину неке телесне шупљине (нпр. језика). - Ове брадавице нервне немаю за покривало никакву кожу, него само балавый полак' прозрачный завитакъ, кой е чврсто на ньима прелепльнъ (ПМ 1844: 18).

балаво тело с <балавом тьлу> доњи слој коже који је састављен од растреситог везивног ткива у којем су корени длачица, као и ћелије које носе пигмент (лат. dermis). - Црна боя, као вообште свака боя людій, има свое мъсто у балавом тьлу исподъ горнъ кожице (ПМ 1844: 119).

бела кожа у оку ж <бъла кожа> задњи, већи део спољашње опне очне јабучице, који има облик лопте која је одсечена на предњем крају, беоњача (лат. sclera). Бъла кожа с'преда у оку продуженіе е внутрениъ коже над'очне (ПМ 1844: 20).

бела џигерица <бъла џигерица> главни део система органа за дисање, у којем се врии размена гасова, плућа (лат. pulmones). - Бъла џигерица состои се 
изъ два мека, шупльикаста, едно съ другимъ свезана, дубоко и косо усекнута тьла, коя сва скупа едно дьло и союзъ имаю (ПМ 1844: 12).

бели мозак м <бђлый мозакъ> бела маса која гради унутрашњост мозга, (лаm. substantia alba). - Матерія обоій овы частій на поверхности е пепелястоугасита, а изнутра бълый мозакъ или тако зовомый мозакь (мозгана масть) (ПМ 1844: 16).

\section{белоџигерна бијућа жила ж} <бълоџигерну біюћу жилу> крвни суд који преноси крв богату угљендиоксидом и отпадним материјама преко периферне цчиркулације од плућа до срияа, плућна артерија (лат. $а$. pulmonalis). - $\mathrm{y}$ другом стаблу подразумьваю се двь главне крвне жиле, сирьчь, шупля жила (Hohlader) коя изъ свію частій тьла скупльну крвъ у десно срчано уво уноси, одкудъ се она у десну срчану камеру, и одатле крозъ бълоџигерну біюћу жилу одводи - и крвна жила, коя крвъ у льво срчано уво уноси, изъ коегъ у леву срчану камеру улази, да одатле теченіе свое на ново почне (ПМ 1844: 11).

бешичица ж <бешичица> постељица $y$ материци око заметка као веза између мајчине крви и емриона, има заштитну улогу и преко юе хранљиве материје $и$ кисеоник доспевају до заметка, постељиияа (лат. placenta). - После нъколико дана види се тамо мала нъка бешичица, у врло танку кожицу умотана, коя беланцету подобну влагу содржава (ПМ 1844: 4).

бијућа жила ж <біюће жиле> жила којом тече крв из срияа у све делове тела, артерија (лат. агtегіa). - Біюће жиле одводе крвъ изъ срца у све части тьла, чимъ се протезанъмъ и скуплянъмъ своій фібра разширую и стешняваю (ПМ 1844: 11).

бистри сок м <бистрый сокъ> безбојна, прозирна, слана течност коју луче жлезде у очној дупљи, суза (лат. lacrimae). - Међу овимъ листовыма содржава се бистрый сокъ и цЊло тьло обкружава нъжна прозрачна кожа, као заклопацъ (ПМ 1844: 21).

брада ж <брада> 1. део лица испод уста (лат. mentum). - Садъ се савія глава тако, да брада на прсима стои... (ПМ 1844: 4); 2. длаке са стране лица и испод yста, код одраслог човека (лат. barba). - [...] А кодъ мушкогъ пола починъ и брада растити (ПМ 1844: 6).

брадавица ж <брадавица > мали израштаји на кожи преко којих се примају надражаји. - Съ поля пуна е малы брадавица, у коима се краеви кожны нерва, орудія осећаня и судићи за непримђтително изпареніе окончаваю (ПМ 1844: 9).

брадавичица ж <брадавичицы> деминутив од брадавица. - Кончићи нерва често се дъле, но опетъ се еданъ съ другимъ союжаваю, и образую дебело оддвоеніе или клупче нерва, кое се са основнымъ частима мозга 
прилично соглашаваю, и многе крвне сосуде содржаваю, или се у замршеным свезама саставляю, кое се плетиво нерва зове, и распростиру се такође у наймань части тъла, па или се у финой балавой кожицы, или у врло нъжной брадавичицы окончаваю (ПМ 1844: 17).

бубрежак м <бубрежцы> парни мокраћни орган у којем се ствара мокраћа, бубрег (лат. ren). - У долньмъ трбуху острагъ међу последньымъ малымъ ребрыма леже бубрежцы, кои се 'изъ фини каналића састое (ПМ 1844: 15).

бутина ж <бутину> део човечје ноге изнад колена. - Руке уметнуте су са горньимъ своимъ частима у нькимъ шупльинама плећны костію [...] а ноге су у таковымъ шупльинама кукова, утврђене, и такође три части имаю, бутину, изподколеницу, (голени) и ноге (ПМ 1844: 9).

\section{B}

велика бијућа жила ж <велика біюћа жила> главни и највећи артеријски суд, који излази из леве срчане коморе, преко чијих грана се снабдева крвљу читав организам, аорта (лат. aоrta). - Одъ обои има двояка главна стабла; [...] - ца е онда велика біюћа жила, коя изъ леве срчане камере, у све части тьла иде [...] (ПМ 1844: 11).

велики мозак м <великій мозакъ> најразвијенији део централног нервног система, састављен од десне и леве хемисфере које су изграђене од сиве и беле масе (лат. telencephalon). - Првый или великій мозакъ, лежи у свой горньой части темена - шупльине, и у долньой до половине (ПМ 1844: 16).

вилица ж <вилице> чељусна кост у коју су усађени зуби. - Теме состои се изъ выше шупльи костію, кое су узубченымъ швомъ увезане; а къ овыма принадлеже такође кости слђпи очію, носъ, небце, и вилице [...] (ПМ 1844: 8).

внутрења кожа <внутрень коже> кожа на унутрашњој страни неких шупљих органа коју покрива слуз, слузокожа. Грло е на подобіе левка каналъ, и есть продуженіе внутрень коже уста [...] (ПМ 1844: 13).

водени судић м <воденымъ судићима> лимфни капилар који одводи лимфу у веће сабирне судове, крећући се са периферије према сриу, једносмерно. Мушкули [...] У ньима се содржаваю (животиня) фибре съ нервыма и кончанымъ плетивомъ, крвнымъ и воденымъ судићима уплетене, и нъкимъ видомъ лепа (туткала) къ цълому едномъ союжене (ПМ 1844: 10).

воздушна цев ж <воздушне цеви> хрскавичава иев од ждрела до плућних крила, кроз који се дише, душник (лат. trachea). - Ови произлазе изъ воздушне цеви, (грла), као изъ едногъ на предньой части врата, и на езычнной кости (гдъ се она грклянъ (Kelhkopf) именуе) висъћем каналу (ПМ 1844: 12).

воздушноцевни

чвор M

<воздушноцЊвнимъ чворомъ> део 
гркљана који се пружа од гласних жица према душнику, доњи спрат, подглотична дупља (лат. cavitas infraglottica). - Найзнаменитіе орудіе говореня есть ресица, съ воздушноцЊвнимъ чворомъ у гркляну, кой е шупля, изъ више рскавица состоећа се цЊвь, и кой се доле у воздушной цъви (грлу) отвара. По томе како е отворъ овай великій или малій, быва и тонъ гласа грубльій или фаиніи (ПМ 1844: 13).

врат м <врата> део тела који спаја главу с трупом. - Ови произлазе изъ воздушне цеви, (грла), као изъ едногъ на предньой части врата, и на езычнной кости (гдђ се она грклянъ (Kelhkopf) именуе) висьћем каналу (ПМ 1844: 12).

вратарна жила ж <вратарна жила> парна крвна жила која оксигенованом крвљу снабдева главу и врат, каротидна aртерија (лат. a. carotis communis). Она е жльзди подобный дробъ, и изъ неброены сосуда саставльна, одъ коій су найзнаменитіе вратарна жила (Pfortader, нЊка крвна жила) црно џигерична біюћа жила, и онда жучъ са своимъ сосудима (ПМ 1844: 14).

вратни ртењачни зглавак ж <вратне ртеняче> покретни приљен на врату који припада групи правих приљенова, чији попречни пресек има отвор кроз који пролази кичмена артерија; вратни приљен (лат. vertabrae cervicales). Главу држи и носи ртеняча, стубъ кой се изъ 24 поедины едно за другимъ движимы зглавкова состои, кои се на вратне ртенячне (плећне) и одъ кукова зглавкове дьле (ПМ 1844: 8).

вратни зглавак м <вратны зглавкова> покретни вратни пршљен који припада групи правих пршљенова, чији попречни пресек има отвор кроз који пролази кичмена артерија, вратни приљен (лат. vertabrae cervicales). - $\mathrm{Ha} 12$ ртенячнымъ зглавковима, кои после 7 вратны зглавкова сльдую, на свакой су страни толико ребара привезаны, одъ коій се горньи 7 у малый кругъ савіяю и са пршномъ костћу са нЊкомъ рскавицомъ свезую (ПМ 1844: 8).

\section{$\Gamma$}

глава ж <главу> горњи део човечјег $u$ одговарајући дио животињског тела у којем је мозак. - Човеческо тьло дьли се на главу, трупъ, и удове (ПМ 1844: 7).

глава чекича ж < главомъ чекича > горюи проширени део кошчице чекића у $y x y$, зглобљен са телом наковња сарит mallei. - Една се зове чекичъ, кой е посредствомъ нькогъ држка са добошномъ кожомъ свезанъ; друга коштица се зове наковань, кой се съ главомъ чекича свезуе, између потеге наковня и треће коштице, на подобіе узенгие, лежи сочиву-подобна коштица, найманя кость у човечіемъ тьлу (ПМ 1844: 19).

голен ж <голени> део ноге од колена до скочног зглоба, који се састоји од голењаче и лишњаче, потколеница. Трупу принадлеже ребра, кичма, и трбухъ (Becken), са осталымъ 
составнымъ частима внутрены (црева); къ удовима пакъ плећа, мишице, руке, голени, и ноге (ПМ 1844: 7).

горка влага ж <горку влагу> лепьива маса жуте до смеђе боје која се лучи из уха, ушна маст (лат. cerumen). - У овомъ има много жльздій, кое горку нъку влагу оддълюю, чрезъ што се ходникъ углађава, и мекшій задржава, а прашини или малымъ наськомымъ улазакъ препречава (ПМ 1844: 19).

горња вилица ж <горньой вилицы> велика, парна кост у средишњем делу лица, која учествује у изградюи очне и носне дупље, као $и$ подслепоочне $u$ криластонепчане јаме (лат. maxilla). Теме состои се изъ выше шупльи костію, кое су узубченымъ швомъ увезане [...] у горньой и дольной вилицы зуби су утврђени, коій одрастанъ човекъ обично 32 има... (ПМ 1844: 8).

горња кожа ж <горня кожа> танак површински слој коже, састављен од епитела који на површини орожава, епидерм (лат. epidermis). - Но ако е горня кожа отврднула, и надула се, онда осећаню долнъ коже или сасвимъ или одъ части препятствуе (ПМ 1844: 18).

горња кожица ж <горнъ кожице> танак површински слој коже, састављен од епитела који на површини орожава, епидерм (лат. epidermis). Црна боя, као вообште свака боя людій, има свое мъсто у балавом тьлу исподъ горнъ кожице (ПМ 1844: 119). горња предња мишица ж <горню предню мишицу> широк троугласти мишић, који базом полази са три снопа, кључне кости, грудне кости и шест првих ребарних хрскавица и горњег дела предњег трбушног зида, велики грудни мишић (лат. pectoralis major). - Руке уметнуте су са горньимъ своимъ частима у нъкимъ шупльинама плећны костію, и имаю три части: раме, мишицу, горню предню мишицу, и руку... (ПМ 1844: 9).

гркљан м <грклянъ> почетни, проширени део доњих дисајних путева и орган у којем се ствара глас (лат. larynx). - Ови произлазе изъ воздушне цеви, (грла), као изъ едногъ на предньой части врата, и на езычнной кости (гдђ се она грклянъ (Kelhkopf) именуе) висьћем каналу (ПМ 1844: 12).

грло с <грло> ждреона дупьа, шупљина с горњим делом гркљана и једњаком. Грло е на подобіе левка каналъ, и есть продуженіе внутрень коже уста... (ПМ 1844: 13).

грожђа кожа ж <грозђа кожа> задњи, највећи део судовне опне очне јабучице, који садржи велики број крвних судова, судовњача (лат. choroidea). - Подъ ньомъ лежи мегка сосудна кожа, кое предня страна зове се дужна кожа, а задня грозђа кожа (ПМ 1844: 20).

груди ж <груд'ма> предюи део човечјег и животињског трупа од врата до mрбуха. - Чистъ воздухъ зове се онай, кой ніе са испареніяма и другимъ станновиднымъ частима претоваренъ, 
коя се смЂша мирисомъ (задисаемъ) одма, и нъкимъ претискиваньмъ (слабленьмъ) у груд'ма познае, и издае (ПМ 1844: 32).

\section{Д}

дванајстопрсно црево с $<12-$-прстно црево> почетни непокретни део танког ирева у човечјем телу који почиње од желуца, дванаестопалачно црево (лат. duodenum). - Почетакъ танкогъ цревета, одъ стомака одма рачунаюћи, зове се 12-прстно црево (Zwölffingerdarm), ербо е одъ прилике 12 прста широко, и 12 цолова дугачко (ПМ 1844: 14); Ова или уходи крозъ жучне ходнике, у дванайстопрстно црево, или се скупля, кадъ е много има, у дольной жучной бешики (ПМ 1844: 14).

дебела темена кожа ж <дебела теменна кожа> спољашьа мождана овојница која обавија мозак и кичмену мождину, тврда мождана опна (лат. duru mater). - Прва е тврда или дебела теменна кожа, коя разнымъ наставцима или продуживаньма, оддъленія у мозгу чини, и осимъ теменяче такође и у кичму и около очны нерва као таблица (Scheide) распорстире се и пружа (ПМ 1844: 16).

дебело гузно црево с <дебело-гузноцрево> завршни део дебелог ирева који се налази у карличној дупљи, дебело ирево (лат. rectum). - Друга црева зову се праздно црево, (Leerdarm), умотано црево, (Grimmdarm), слепо црево, (Blinddarm), криво црево, (Krummdarm), и дебело-гузно-црево, (Mastdarm) (ПМ 1844: 14).

дебело одвојеније с <дебело оддвоеніе> мноштво густо испреплитаних нерава, нервни сноп. - Кончићи нерва често се дъле, но опетъ се еданъ съ другимъ союжаваю, и образую дебело оддвоеніе или клупче нерва, кое се са основнымъ частима мозга прилично соглашаваю, и многе крвне сосуде содржаваю. или се у замршеным свезама саставляю, кое се плетиво нерва зове, и распростиру се такође у найманъ части тъла, па или се у финой балавой кожицы, или у врло нЊжной брадавичицы окончаваю (ПМ 1844: 17).

дебело црево с <дебеломъ цревету> заврини део система органа за варење који се пружа од завриног дела танког чрева до чмарног отвора. - Ова иде иза воздушне цъвы и срчане кесе крозъ кожицу на лажицы у долню часть трбуха, образуе тамо стомакъ и црева, и напоследку окончава се на дебеломъ цревету (ПМ 1844: 13).

дебљина ж <дебльина> масне наслаге у телу човека и неких животиња, сало, маст (лат.unguen). - Подъ кожомъ и међу разнымъ частима животиня лежи мастъ (сало, дебльина), као у кончаномъ плетиву... (ПМ 1844: 10).

десна срчана камера ж <десне срчане камере, десну срчану камеру> део срияа који има облик пирамиде, са базом окренутом позади, на којој се налазе два отвора: десни преткоморно-коморни отвор и отвор плућног артеријског 
стабла; десна срчана комора (лат. ventriculus dexter). - Одъ обои има двояка главна стабла; едно се разширива све то съ маньимъ гранчицама крозъ сво тъло, и ово е џигерна біюћа жила, коя изъ десне срчане камере произлази, и крвъ у белу џигерицу и т. д. носи - ца е онда велика біюћа жила, коя изъ леве срчане камере, у све части тьла иде; у другом стаблу подразумњваю се двђ главне крвне жиле, сирьчь, шупля жила (Hohlader) коя изъ свію частій тьла скупльну крвъ у десно срчано уво уноси, одкудъ се она у десну срчану камеру, и одатле крозъ бълоџигерну біюћу жилу одводи... (ПМ 1844: 11).

десно срчано уво с <десно срчано уво> део срияа на спољашњем зиду десне срчане коморе, кроз који се, посредством шупье жиле, крв преноси из свих делова тела до плућа, десни увасти наставак, десна аурикула (лат. auricula dextrum). - Одъ обои има двояка главна стабла; [...] у другом стаблу подразумъваю се двђ главне крвне жиле, сирьчь, шупля жила (*) коя изъ свію частій тьла скуплЊну крвъ у десно срчано уво уноси, одкудъ се она у десну срчану камеру, и одатле крозъ бълоџигерну біюћу жилу одводи - и крвна жила, коя крвъ у льво срчано уво уноси, изъ коегъ у леву срчану камеру улази, да одатле теченіе свое на ново почне (ПМ 1844: 11).

добошна кожа ж <добошна кожа> затегнути део бубне опне (лат. pars tensa). - Овдъ, на краю е добошна кожа, на подобіе яйца, танка, но тврдо разтегнута кожа, коя е врло чувствителна (ПМ 1844: 19).

добошна шупљина ж <добошне шупльине> део средњег уха, смештен између спољашьег ушног канала и унутрашьег уха, у којем се налазе чекић, наковањ и узенгија, бубна дупља (лат. cavitas tympani). - Ова оддълюе ходникъ чувеня одъ добошне шупльине, у коіой се четири една съ другомъ свезане коштице налазе (ПМ 1844: 19).

долња вилица ж < долня вилица > кост лица која се састоји од тела и гране доње вилице (лат. mandibula). - После 2 месеца плодъ е два цолла дугачакъ шупльикасте кости на рукама и ногама видиме су, и ясно се може видити, да се долня вилица исподъ горнъ попружила (ПМ 1844: 4).

долња кожа ж <долнь коже> доњи део коже $y$ којем су смештени крвни капилари, живции коже, длаке, знојне, лојне жлезде и глатке мишићне ћелије, које су везане за корен длаке, крзно (лат. dermis). - Но ако е горня кожа отврднула, и надула се, онда осећаню долнъ коже или сасвимъ или одъ части препятствуе (ПМ 1844: 18).

долњи трбух м <долньгъ трбуха> доњи део трбушне дупье у којем се налазе део дванаестопалачног ирева, вијуге покретног дела танког ирева и највећи део дебелог ирева, доњи или подмезоколични спрат абдомена. Црна џигерица, найвеће внутреннь (црево), долньгъ трбуха, лежи на десной 
страни подъ краткимъ ребрима (ПМ 1844: 14).

дољна жучна бешика ж <дольной жучной бешики> мишићно-слузокожни орган који служи као резервоар жучи, жучна кесица (лат. vesica biliaris). Ова или уходи крозъ жучне ходнике, у дванайстопрстно црево, или се скупля, кадъ е много има, у дольной жучной бешики (ПМ 1844: 14).

дроб м <дробъ> унутрашњи орган (лат. viscera). - Црна џигерица, найвеће внутреннъ (црево), долньгъ трбуха, лежи на десной страни подъ краткимъ ребрима. Она е жлъзди подобный дробъ, и изъ неброены сосуда саставльна, одъ коій су найзнаменитіе вратарна жила (Pfortader, нъка крвна жила) црно џигерична біюћа жила, и онда жучъ са своимъ сосудима (ПМ 1844: 14).

дугуљасти мозак м <дугулястый мозакъ> мождана маса која испуњава канал кичме, кичмена мождина (лат. medulla spinalis). - Трећа часть зове се дугулястый мозакъ, и состои се изъ свезе мозганы фибра великогъ и малогъ мозга, лежи на кости заднъ части главе (ћушке), и продужуе се, почемъ крозъ шупльину ове, у шуплину зглавкова кичмены иде, у кичмену масть (мозакь) (ПМ 1844: 16).

дужна кожа ж <дужна кожа> обојена прстенаста опна око зенице у оку, дужийа (лат. iris). - Дужна кожа (iris) има на подобіе зракова пруге, кое су подъ нЊки людій црне, црнкасте, кодъ
нБки плаве, и т. д. по чему и бою очію вообшче именуемо (ПМ 1844: 20).

$\mathbf{b}$

Ђубре с <ђубре> крајњи отпадни продукт у процесу варења, који се избаиује кроз анус, измет, (лат. feces). У цревы се сваривань ела, кое е стомакъ почео, продужава, питателный сокъ се последствомъ тамо налазећи се сосуда одъ ела оддвоява, а ђубре избацуе (ПМ 1844: 14).

\section{Ж}

живац м <живцы> влакнасти орган $у$ човечјем или животињском телу који преноси чулне надражаје, вољне $u$ невољне, нехотичне покрете, нерв (лат.

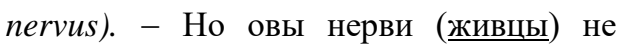
налазе се у танкой горньой кожицы, него у овой, подъ овомъ лежећой ячой кожи у виду малы брадавица (ПМ 1844: 18).

живац виђења м <живацъ виђеня> оптички живац који је задужен за спајање ока са мозгом, очни нерв (лат. n. opticus). - Живацъ виђеня овай дебео е одъ прилике као гушчіе перо, и изъ мозга у очну ябуку улази крозъ шупльину очиу (ПМ 1844: 21).

жила ж <жиле> крвни суд (лат. vasa sanguinea). - Темењача (кость на темену) е горе мало отворена тако, да се біенъ жиле у мозгу осетити може (ПМ 1844: 4).

жлезда ж <жльздама> орган у човечјем или животиьском телу који излучује 
различите врсте сокова. - Црева су опеть на дебелой нъкой кожи, коя се марамица (Gekröse), зове, утврђена, коя се у двострукимъ листићима показуе, кои су масћу, жлђздама, и сосудима напунъны, и гди се на подобіе плювачке сокъ одъ марамице (Gekrösesaft), оддвоява, кои се у прво црево излива, да смешаванъ мастны и водены частица у елыма подпомаже (ПМ 1844: 14).

жлездица < жльздице> деминутив од жлезда. - Она се яко протегнути може, и да бы витка заостати могла, има у нутри подъ ньомъ жльздице, кое зейтинаву влагу оддълюю (ПМ 1844: 9).

жуч ж <жучъ> жуто-зелена течност, текућина горког укуса коју излучује јетра преко жучне кесе (лат. bilis). Жучь е сапунява течность, коя препитанія сокъ изъ ела разтвара, почемъ она мастне и водене части союжава, и отудъ млечный сокъ преправля (ПМ 1844: 14).

жучни ходник м <жучне ходнике> жучни канал који омогућује пренос жучи до дванаестопалачног ирева. Ова или уходи крозъ жучне ходнике, у дванайстопрстно црево, или се скупля, кадъ е много има, у дольной жучной бешики (ПМ 1844: 14).

3

зачатије с <зачатіе> зачетак плода, заметак, ембрион (лат.етьrуо). Препитаніе добива плодъ (embrio зачатіе) посредствомъ пантльике одь пупка (пуповину) крозь празднину материце (Mutterkuchen) изъ крви матере (ПМ 1844: 4).

звезда ж <звезда> отвор на дужици кроз који светлост продире $y$ унутрашьост ока, зеница (лат. pupilla). - Звезда се при слабой свђтлости и помрчини разшируе, а при великой свЂтлости сужава се, безъ да мы штогођь о томе знамо или осећамо (ПМ 1844: 20).

Зглавак м <зглавкова> cnoj двеју или више костију, зглоб (лат. articulatio). Крсти, кое се кодъ дъце изъ 5 зглавкова, а кодъ одрастны изъ троугленне кости состое, у коіой су они 5 зглавкова срастли, нису движиме, образую съ 4 и 5 одъ кука зглавкомъ крсть (ПМ 1844: 9).

зглавак кичмени м <зглавкова кичмены> спој између тела два суседна приљена, кичмени зглоб (лат. articulatio interverberalis). - Трећа часть зове се дугулястый мозакъ, и состои се изъ свезе мозганы фибра великогъ и малогъ мозга, лежи на кости заднъ части главе (ћушке), и продужуе се, почемъ крозъ шупльину ове, у шуплину зглавкова кичмены иде, у кичмену масть (мозакь) (ПМ 1844: 16).

зглавак кука м <кукова зглавкове> cnoj између карличне кости и горњег окрајка бутне кости, зглоб кука (лат. articulatio coxae). - Главу држи и носи ртеняча, стубъ кой се изъ 24 поедины едно за другимъ движимы зглавкова состои, кои се на вратне ртеняче (плећне) и одъ кукова зглавкове дњле (ПМ 1844: 8). 
зеница ж <зеницу> кружни отвор на дужици кроз који светлост продире у унутрашњост ока (лат. pupilla). - Ова у среди има звњзду (зеницу) округлу едну яму, крозъ кою се до дна ока видити може (ПМ 1844: 20).

зној м <зноя> бистра течност која садржи око 99\% воде и делове мокраћне киселине, а служи за регулисање телесне температуре, спречавање развијања бактерија и гљивица на кожи (лат. sudor). - Надочна кожица (Augenlieder) чува ій одъ сваке опасности, и покрива ій при приближаваню ове; трепавице чуваю ій одъ прашине и насъкомы, а обрве служе одъ части за украшеніе, а одъ части за удржаванъ доле текућегъ зноя (ПМ 1844: 20).

зуб м <зуби> беличаста, коштана плочица, усађена у вилици, која служе за кидање и дробљење хране у устима (лат. dens). - У прелазку дътинства (кое ce ca 7. годиномъ окончава, кадъ први зуби испадаю) у юношество... (ПМ 1844: $6)$.

\section{И}

исподколеница ж < изподколеницу> део ноге од колена до скочног зглоба, који се састоји од голеначе и лишьаче, потколеница. - Руке уметнуте су са горньимъ своимъ частима у нькимъ шупльинама плећны костію [...] а ноге су у таковымъ шупльинама кукова, утврђене, и такође три части имаю, бутину, изподколеницу, (голени) и ноге (ПМ 1844: 9). извијен ходник м <извіенъ ходникъ> део унутрашьег уха у коме је иентар за равнотежу, лавиринт (лат. labyrinthus). - После добошне шупльине сльдуе лабиринтъ или извіенъ ходникъ, у коегъ средини се мала шупльина, преддворіе, а одъ горе и сапреда се три на подобіе лука цевчице, кое се са петъ улійва у преддворію отвараю, - а доле се на подобіе пужа увіенъ каналъ налази (ПМ 1844: 20).

\section{J}

јајце с <яйцету> јајна ћелија (лат. ovulum). - Првый зачетакъ по свой прилицы лежи у плодномъ яйцету, кое крозъ каналчићь едан тако назван трумпета (Muttertrompete) у материцу уђе, и тамо се утврди (ПМ 1844: 3).

језик м <есыку> покретљиви мишић $y$ усној шуплини човека и виших животиьа који служи као орган за укус, за жвакање и гутање хране, а код човека помаже при стварању $u$ извођену гласова и говора (лат. linguа). - Вкусъ се проузроковава, чрезъ мложину нервны брадавица, кое се на есыку $^{1}$ налазе, и на кое слане и зейтинаве частице ела втеченіе чине разликую (ПМ 1844: 18).

језична кост ж <езычнной кости> кост изнад гркљана, слична потковици, подјезична кост (лат. os hyoides). - Ови

1 Вероватно је реч о штампарској грешци, те је термин транскрибован као језик. 
произлазе изъ воздушне цеви, (грла), као изъ едногъ на предньой части врата, и на езычнной кости (гдъ се она грклянъ (Kelhkopf) именуе) висьћем каналу (ПМ 1844: 12).

\section{$\mathbf{K}$}

канал м <каналъ> шупаљь $и$ ваљкаст, дужи или краћи орган у организму кроз који пролазе разне материје (лат. canalis). - После добошне шупльине сльдуе лабиринтъ или извіенъ ходникъ, у коегъ средини се мала шупльина, преддворіе, а одъ горе и сапреда се три на подобіе лука цевчице, кое се са петъ улійва у преддворію отвараю, - а доле се на подобіе пужа увіенъ каналъ налази (ПМ 1844: 20).

каналчић м <каналчићемъ> деминутив од канал. - Првый зачетакъ по свой прилицы лежи у плодномъ яйцету, кое крозъ каналчићь едан тако назван трумпета (Tuttertromnete) у материцу уђе, и тамо се утврди (ПМ 1844: 3).

кичма ж <кичма> коштани стуб састављен од пршљенова, који чини средину костура код човека и виших жсивотиња (лат. columna verberalis). Трупу принадлеже ребра, кичма, и трбухь (Becken), са осталымъ составнымъ частима внутреины (црева); къ удовима пакъ плећа, мишице, руке, голени, и ноге (ПМ 1844: 7).

кичмена маст ж <кичмену масть> централни орган нервног система $у$ човека и других кичменака, мека материја која испуњава лобағу $и$ кичмени канал, мозак (лат. cerebrum). Трећа часть зове се дугулястый мозакъ, и состои се изъ свезе мозганы фибра великогъ и малогъ мозга, лежи на кости заднъ части главе (ћушке), и продужуе ce, почемъ крозъ шупльину ове, у шуплину зглавкова кичмены иде, у кичмену масть (мозакь) (ПМ 1844: 16).

клупче нерва с <клупче нерава> мноштво густо испреплитаних нерава. - Кончићи нерва често се дъле, но опетъ се еданъ съ другимъ союжаваю, и образую дебело оддвоеніе или клупче нерва, кое се са основнымъ частима мозга прилично соглашаваю, и многе крвне сосуде содржаваю... (ПМ 1844: 17).

кључна кост ж <ключнымъ костима> дуга кост која спаја грудну кост $\mathrm{c}$ лопатицом, кључњача (лат. clavicula). Горе надъ ребрыма леже обе плећне кости, и свезую се ключнымъ костима са пршномъ костћу (ПМ 1844: 9).

кожа ж <кожа> спољни омотач човечјег тела (лат. dermis). - Кожа, коя е свойственно нъко плетиво одъ кончића, и коя е крвлю и нервима изплетена, обкружава цьло тьло (ПМ 1844: 9).

кожица ж <кожицу> танки слој коже (лат. pellicula). - После нъколико дана види се тамо мала нъка бешичица, у врло танку кожицу умотана, коя беланцету подобну влагу содржава (ПМ 1844: 4).

кожни канал м <кожне канале> мишићно-слузокожни канал који 
спроводи мокраћу од бубрега до мокраћне бешике, мокраћовод (лат. ureter). - Они къ тому служе, да мокраћу изъ крви оддълюю, коя се крозъ кожне канале у мокраћну бешику излива, одъ куда она крозъ свое канале (Harnröhre) у тайне удове тьла одлази, и избацуе се (ПМ 1844: 15).

кожно закривало с <кожномъ закривалу> везивно ткиво којим је обложен сваки живац, епинеуријум. Они су пантльичице одъ поособны врло фины бълы кончића, кои су средствомъ нЊжногъ шупльгъ плетива саставльни, и у врло танкомъ кожномъ закривалу умотани (ПМ 1844: 17).

колено с <кольна> чланак на људској нози који спаја бедрену кост са голеничком кости (лат. gепи). - Сад се савія глава тако, да брада на прсима стои; кольна су у высину, кадкадъ до вилице дигнута, ноге су натрагъ отишле (ПМ 1844: 4).

кончић м <кончићи> кончасти део ткива, влакно (лат. туопета). - У истој се виде мали союжени кончићи, изъ коій после седамъ дана дугулясто, готово провидно клупченце постане, одъ коега средине па до кожице нъки су кончићи пружени, кои су почетакъ цревета одъ попка (ПМ 1844: 4).

кончић нерва м <кончићи нерва> нервно влакно. - Кончићи нерва често се дњле, но опетъ се еданъ съ другимъ союжаваю, и образую дебело оддвоеніе или клупче нерва, кое се са основнымъ частима мозга прилично соглашаваю, и многе крвне сосуде содржаваю или се у замршеным свезама саставляю, кое се плетиво нерва зове, и распростиру се такође у найманъ части тъла, па или се у финой балавой кожицы, или у врло нъжной брадавичицы окончаваю (ПМ 1844: 17).

коса ж <коса> длака на човечјој глави (лат. capillum). - Коса произлази изъ оногъ кончастогъ плетива изподъ коже, изъ кожногъ, судића пуногъ клупчета, кое опетъ друго клупче у себи садржава, у коему коса сокомъ нькимъ покривена лежи (ПМ 1844: 10).

кост ж <костію> један од тврдих делова човечјег тела или животиња кичмењака (лат. os). - НБгово тьло истина состои се такође, као и други совершенны животиня, изъ коже, меса, костію, крви, и т. д. накратко изъ штофа (есенціалны частій) животиня тьла; но соразмьрно великій мозакъ, и врло утончани нерви само нЊму приличе и припадаю (ПМ 1844: 1).

кост на темену ж <кость на темену> парна пљосната испупчена кост, четвртастог облика која гради кров лобане, темена кост, темењача (лат. os parietale). - Темењача (кость на темену) е горе мало отворена тако, да се біенъ жиле у мозгу осетити може (ПМ 1844: 4).

коштица ж <коштице> деминутив од кост, ситна кост. - Долнь части су нъкимъ видомъ свеза съ горныма утврђене, и на ньима се налазе многе мале коштице, кое ручне и ножне 
коричке сачиняваю, после коій онда прсти на рукама и ногама сльдую (ПМ 1844: 9).

кошчана шупљина ж <кошчанымъ шупльинама> уздужни каналић у кости y којој се налази коштана срж. - Ове леже у кошчанымъ шупльинама на некомъ лежиру одъ масти; пакъ се средствомъ 6 мушкула на све стране окрећу (ПМ 1844: 20).

кратко ребро с <кратка ребра> најкраће, највише закривљено ребро и спљоштено одозго надоле, прво ребро (лат. costa prima). - На 12 ртенячнымъ зглавковима, кои после 7 вратны зглавкова сльдую, на свакой су страни толико ребара привезаны, одъ коій се горньи 7 у малый кругъ савіяю и са пршномъ костћу са нъкомъ рскавицомъ свезую; а друга су 5 кратка или фалична ребра (ПМ 1844: 9).

крв ж <крви> ирвена текућина, течност која тече кроз крвне жиле, судове човечјег и животинског организма, храни га и врши измену твари, материје у њему (лат. sanguis). -

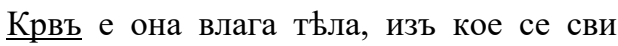
други сокови преправляю и оддълюю (ПМ 1844: 12).

крвна жила ж <крвне жиле> део кардиоваскуларног система чија је функција враћање крви у срие, вена (лат. venae). - Крвне жиле доводе крвъ къ срцу, све се већма къ нъму разширую, и имаю по већой части прилопке, кои враћанъ напредъ отишавше крви предупређую (ПМ 1844: 11).

крвна жила вратарна ж <крвна жила вратарна> вена која настаје иза главе панкреаса спајањем горье цревне и слезинске вене, чије се стабло пружа навише, долази до улазних врата јетре, где се рачва на своје две завршне гране, десну и леву, вена порте (лат. vепа portae hepatis). - Изь крви, кою она крвна жила вратарна у црну џигерицу доводи, оддьлю се жучъ (ПМ 1844: 14).

крвни сосуд м <крвни сосуди> дио кардиоваскуларног система, чија је функиија преношење крви кроз тело, крвни суд (лат. vasa sanguinea). Увлаченъмъ и изпуштавъмъ воздуха, џигерица се на объма странама и разшируе и скупля, а чрезъ то се и крвни сосуди часъ стешнюю, а часомъ разширую (ПМ 1844: 15).

крвни судић м <крвнымъ судићима> мали крвни суд. - У ньима се содржаваю (животиня) фибре съ нервыма и кончанымъ плетивомъ, крвнымъ и воденымъ судићима уплетене, и нъкимъ видомъ лепа (туткала) къ цълому едномъ союжене (ПМ 1844: 10).

криво црево $\mathrm{c}<$ криво црево> покретни део танког ирева, који се састоји од 11-12 вијуга, а чији се заврини део спаја са почетним делом дебелог ирева, усукано црево (лат. ileum). - Друга црева зову се праздно црево, (Leerdarm), умотано црево, (Grimmdarm), слепо црево, (Blinddarm), криво црево, 
(Krummdarm), и дебело-гузно-црево, (Mastdarm) (ПМ 1844: 14).

кристално сочиво с <кристално сочиво> сабирно сочиво ока, смечтено иза дужице, а састављено од многобројних провидних слојева (лат. lens). - Но иза дужне коже међу двема влагама (тако зововымъ воденомъ и оном' другомъ на подобіе стакла) лежи кристално сочиво овога на объма странама узвышено тьло, кое се изъ више прозрачны листова состои (ПМ 1844: 21).

крсти ж <крста> троугласта кост настала срастанем пет крсних приљенова који припадају групи лажних приљенова (лат. os sacrum).- Крсти, кое се кодъ дъце изъ 5 зглавкова, а кодъ одрастны изъ троугленне кости состое, у коіой су они 5 зглавкова срастли, нису движиме, образую съ 4 и 5 одъ кука зглавкомъ крстъ (ПМ 1844: 9).

кук м <кукови> избочени део човечјег тела између бокова и бедрене кости (лат. os coxa). - Такође меснати листови, округли яки кукови, широка плећа, лепъ вид главе, благородно изображеніе лица, на комъ уста нису као у маймуна губица изпубчена, горня устна съ малымъ танкимъ (на среди) каналићемъ, и друга свойства има само човеческо тьло (ПМ 1844: 1).

кутњак м <кутняцы> зуб који служи за жвакање, кутњи зуб (лат. dentes molares). - У седмомъ месецу, или и поздніе нъшто, а често и при концу прве године, изиђу предньи зуби, ньи 7, а доциіе псећіи или очни, а съ концемъ прве године, или у другой кутняцы, поредъ свакогъ очняка 4 (ПМ 1844: 5).

\section{Л}

лабиринт м <лабиринтъ > део

унутрашьег уха у коме је центар за равнотежу, лавиринт (лат. labyrinthus). - После добошне шупльине сльдуе лабиринтъ или извіенъ ходникъ, у коегъ средини се мала шупльина, преддворіе, а одъ горе и сапреда се три на подобіе лука цевчице, кое се са петъ улійва у преддворію отвараю, - а доле се на подобіе пужа увіенъ каналъ налази (ПМ 1844: 20).

лажица ж <лажицы> пречага у човечјем телу која одваја грудну дупљу од трбушне, дијафрагма (лат. processus xiphoideus). - Ова иде иза воздушне цъвы и срчане кесе крозъ кожицу на лажицы у долню часть трбуха, образуе тамо стомакъ и црева, и напоследку окончава се на дебеломъ цревету (ПМ 1844: 13).

лажичица ж <лажичицомъ> пречага $y$ човечјем телу која одваја грудну дупљу од трбушне, дијафрагма (лат. processus xiphoideus). - Пршна шупльина одъ долньгъ трбуха оддњлена е лажичицомъ, коя е на прсима узвышена, а у нутри у долньмъ трбуху шупля (ПМ 1844: 15).

лева срчана камера ж <леве срчане камере, леву срчану камеру> највећа срчана шупљина у облику спљоштене купе, са базом окренутом уназад, на чијој се основи виде два отвора: леви 
преткоморно-коморни и отвор, лева срчана комора (лат. аорте ventriculus sinister). - Одъ обои има двояка главна стабла; едно се разширива све то съ маньимъ гранчицама крозъ сво тъло, и ово е џигерна біюћа жила, коя изъ десне срчане камере произлази, и крвъ у белу џиферицу и т. д. носи, - ца е онда велика біюћа жила, коя изъ леве срчане камере, у све части тъла иде; у другом стаблу подразумђваю се двђ главне крвне жиле, сирђчь, шупля жила (Hohlader) коя изъ свію частій тьла скупльну крвъ у десно срчано уво уноси, одкудъ се она у десну срчану камеру, и одатле крозъ бълоџигерну біюћу жилу одводи - и крвна жила, коя крвъ у льво срчано уво уноси, изъ коегъ у леву срчану камеру улази, да одатле теченіе свое на ново почне (ПМ 1844: 11).

лево срчано уво с <льво срчано уво> део сриа кроз који се крв транспортује до леве преткоморе, а налази се на ьеном спољашьем зиду, лева аурикула (лат. auricula sinistra). - У другом стаблу подразумњваю се двђ главне крвне жиле, сирьчь, шупля жила (Hohlader) коя изъ свію частій тьла скупльну крвъ у десно срчано уво уноси, одкудъ се она у десну срчану камеру, и одатле крозъ бълоџигерну біюћу жилу одводи - и крвна жила, коя крвъ у льво срчано уво уноси, изъ коегъ у леву срчану камеру улази, да одатле теченіе свое на ново почне (ПМ 1844: 11).

лист м <листови> задюи, меснати, доњи део ноге (лат. solea). - Такође меснати листови, округли яки кукови, широка плећа, лепъ вид главе, благородно изображеніе лица, на комъ уста нису као у маймуна губица изпубчена, горня устна съ малымъ танкимъ (на среди) каналићемъ, и друга свойства има само човеческо тъло (ПМ 1844: 1).

лице с <лица> предюа страна главе у човека (лат. facies). - Такође меснати листови, округли яки кукови, широка плећа, лепь вид главе, благородно изображеніе лица, на комъ уста нису као у маймуна губица изпубчена, горня устна съ малымъ танкимъ (на среди) каналићемъ, и друга свойства има само човеческо тьло (ПМ 1844: 1).

\section{M}

мали мозак м <малый мозакъ> део мозга који се налази у задњој лобањској јами, састоји се из сиве и беле масе, а основна улога му је регулачија моторне активности и тонуса скелетне мускулатуре (лат. cerebellum). - Подъ овыма острагъ лежи малый мозакъ, кой е хоризонталнымъ продуженіемъ тврде темена-коже одъ претискиваня великогъ сачуванъ (ПМ 1844: 16).

марамица ж <марамица, марамице> опна којом су обложена ирева (лат. peritoneum). - Ц - Црева су опеть на дебелой нъкой кожи, коя се марамица (Gekröse), зове, утврђена, коя се у двострукимъ листићима показуе, кои су масћу, жльздама, и сосудима напунђны, и гди се на подобіе плювачке сокъ одъ марамице (Gekrösesaft), оддвоява, кои се 
у прво црево излива, да смешавань мастны и водены частица у елыма подпомаже (ПМ 1844: 14).

маст ж <мастъ> масне наслаге у телу човека и неких животиња, сало (лат. unguen). - - Подъ кожомъ и међу разнымъ частима животиня лежи мастъ (сало, дебльина), као у кончаномъ плетиву... (ПМ 1844: 10).

материца ж <материцу> унутрашњи женски полни орган у којем се плод развија до порођаја (лат. uterus). Првый зачетакъ по свой прилицы лежи у плодномъ яйцету, кое крозъ каналчићь едан тако назван трумпета (Muttertrompete) у материцу уђе, и тамо се утврди (ПМ 1844: 3).

месо с <меса> мекано, мишићно ткиво човечјег тела (лат. саго). - Мушкули, особитый родъ кончића, кои къ движенію удова служе, образую месо (ПМ 1844: 10).

мишица ж <мишица> део руке од рамена до лакта, надлактни мишић (лат. brachium). - Трупу принадлеже ребра, кичма, и трбухъ (Becken), са осталымъ составнымъ частима внутреины (црева); къ удовима пакъ плећа, мишице, руке, голени, и ноге (ПМ 1844: 7).

млечна кеса ж <млечна кеса> орган из којег се развијају лимфни судови, лимфна кеса. - Млечна кеса излива сокъ препитанія у пршный ходъ, танакъ еданъ каналъ, кой по кичми горе у высину иде, и кои се даль и на львой страни, из'а велике біюће жиле, у крвну жилу на львой ключной кости одводи (ПМ 1844: 15).

млечни сок м <млечный сокъ $>$ жутозелена течност, горка течност коју излучује јетра преко жучне кесе, жуч (лат. bilis). - Овай млечный сокъ пролази крозъ нъке каналчиће у млечне сосуде марамице, (Gekrösec), гди се воденомъ нькомъ течносћу утончава и скупля се у млечный судъ, кой е кожна поредъ кичме у предълу найгорньгъ зглавка одъ кукова лежећа кеса (ПМ 1844: 14).

млечни сосуд м <млечне сосуде> мишићно-слузокожни орган који служи као резервоар жучи, жучна кеса (лат. vesica biliaris). - Овай млечный сокъ пролази крозъ нъке каналчиће у млечне сосуде марамице, (Gekrösec), гди се воденомъ нькомъ течносћу утончава и скупля се у млечный судъ, кой е кожна поредъ кичме у предълу найгорньгъ зглавка одъ кукова лежећа кеса (ПМ 1844: 14).

млечни суд м <млечный судъ $>$ мишићно-слузокожни орган који служи као резервоар жучи, жучна кеса (лат. vesica biliaris). - Овай млечный сокъ пролази крозъ нъке каналчиће у млечне сосуде марамице, (Gekrösec), гди се воденомъ нькомъ течносћу утончава и скупля се у млечный судъ, кой е кожна поредъ кичме у предълу найгорнђгъ зглавка одъ кукова лежећа кеса (ПМ 1844: 14). 
мозак м <мозакъ> мека материја која испуњава лобању и кичмени канал (лат. cerebrum). - Кости, кое строй човеческогъ тьла подупиру, и у свези држе, есу тврде, круте, съ масномъ матеріомъ, коя се мозакъ (мастъ у кости) зове, напунъне части, кое свою особиту величину, видъ и опредьленіе имаю (ПМ 1844: 8).

мозгана кожа <мозганомъ кожомъ> функционално најважнији део ока који садржи рецепторе за светлост и боје, мрежнача (лат. retina). - Найпосле сасвимъ острагу одевено е око са мрежномъ или мозганомъ кожомъ коя изъ виђеня живца произлази (ПМ 1844: 21).

мозгана маст <мозгана масть> мека материја која испуюава лобању $u$ кичмени канал, мозак (лат. сегеbrum). Матерія обоій овы частій на новерхности е пепелясто-угасита, а изнутра бълый мозакъ или тако зовомый мозакъ (мозгана масть) (ПМ 1844: 16).

мокраћа ж <мокраћу> течност коју луче бубрези и која се кроз мокраћне органе излучује из тела (лат. итіnа). Они къ тому служе, да мокраћу изъ крви оддълюю, коя се крозъ кожне канале у мокраћну бешику излива, одъ куда она крозъ свое канале (Harnröhre) у тайне удове тъла одлази, и избацуе се (ПМ 1844: 15).

мокраћна бешика ж <мокраћну бешику> иупљи слузокожно-мишићни орган, у којем се скупьь мокраћа у периоду између два пражнења (лат. vesica urinaria). - Они къ тому служе, да мокраћу изъ крви оддђлюю, коя се крозъ кожне канале у мокраћну бешику излива, одъ куда она крозъ свое канале (Harnröhre) у тайне удове тьла одлази, и избацуе се (ПМ 1844: 15).

мрежица ж <мрежицомъ> серозна опна која покрива унутрашьу површину зидова трбуха и карлице, али и неке органе у перитонеалној дупљи, трбушна марамица (лат. peritoneum). Шупльина трбуха обучена е кожицомъ одъ црева; надъ ньомъ преко танки црева прострта е кожица, коя се мрежицомъ зове, коя е кодъ дебелы людій млогомъ мастћу уткана, и коя къ мекой подлоги за црева, за ньіово овлаженъ и утопляванђ, а къ другимъ памъреніяма служи (ПМ 1844: 15).

мрежна кожа ж <мрежномъ кожомъ> функиионално најважнији део ока који садржи рецепторе за светлост и боје, мрежнача (лат. retina). - Найпосле сасвимъ острагу одевено е око са мрежномъ или мозганомъ кожомъ коя изъ виђеня живца произлази (ПМ 1844: 21).

мрежна кожица ж <мрежна кожица> део епитела за који се веровало да утиче на пигментащију. - Помеђу овымъ брадавицама находи се нька балава матерія, коя се мрежна кожица зове, помеђу танкимъ горньимъ кожицама провучена, и коя разне бое човеческогъ тела проузрокуе (ПМ 1844: 10). 
мушкул м <мушкули> еластичан орган који грчењем $u$ опружањем врии покрете делова тела и тако омогућава кретање читавог организма, мииић (лат. musculus). - Мушкули, особитый родъ кончића, кои къ движенію удова служе, образую месо (ПМ 1844: 10).

\section{H}

надочна кожица ж <надочна кожица> покретљиви набор коже који итити око, очни капак (лат. blepharospasmus). - Надочна кожица (Augenlieder) чува ій одъ сваке опасности, и покрива ій при приближаваню ове; трепавице чуваю ій одъ прашине и наськомы, а обрве служе одъ части за украшеніе, а одъ части за удржавакь доле текућегъ зноя (ПМ 1844: 20).

наковањ м <наковня, наковань> једна од коичица средюег уха (лат. incus). Една се зове чекичъ, кой е посредствомъ нькогъ држка са добошномъ кожомъ свезанъ; друга коштица се зове наковань, кой се съ главомъ чекича свезуе, између потеге наковня и треће коштице, на подобіе узенгие, лежи сочиву-подобна коштица, найманя кость у човечіемъ тьлу (ПМ 1844: 19).

непце с <небце> горња повриина усне дупље код кичмењака (лат. palatum). Теме состои се изъ выше шупльи костію, кое су узубченымъ швомъ увезане; а къ овыма принадлеже такође кости сльпи очію, носъ, небце, и вилице... (ПМ 1844: 8). нерв м <нерви> један од влакнастих органа у људском или жсивотињском телу који се од мозга и кичмене мождине гранају по целом телу, преносећи чулне надражаје, живач (лат. nervus). - НБгово тьло истина состои се такође, као и други совершенны животиня, изъ коже, меса, костію, крви, и т. д. накратко изъ штофа (есенціалны частій) животиня тьла; но соразмњрно великій мозакъ, и врло утончани нерви само нъму приличе и припадаю (ПМ 1844: 1).

нерв мирисања м <нерви мирисаня> мождани жсивац који полази од биполарних ћелија смештених на мирисном пределу слузокоже горнег дела носне дупље, горнег дела носне преграде $и$ горье носне икољке, мирисни жсивау (лат. пn. olfactori). Надъ овомъ кожомъ распрострети су нерви мирисаня, кои изъ мозга долазе, и крозъ коштицу на подобіе сита у ноздрве се спуштаю (ПМ 1844: 18).

нервна брадавица ж <нервны брадавица> рецептор чула укуса на слузокожи језика преко којих се примају надражаји, густативна папила (лат. caliculi gustatorii). - Вкусъ се проузроковава, чрезъ мложину нервны брадавица, кое се на есыку налазе, и на кое слане и зейтинаве частице ела втеченіе чине (ПМ 1844: 18).

нога ж <ноге> крајюи, доюи део тела човека и животиња, од бока наниже, који служи за ходање (лат. реs). - Руке уметнуте су са горньимъ своимъ 
частима у нькимъ шупльинама плећны костію [...] а ноге су у таковымъ шупльинама кукова, утврђене, и такође три части имаю, бутину, изподколеницу, (голени) и ноге (ПМ 1844: 9).

ножна коричка ж <ножне коричке> крајюи, доњи део тела човека и животиња, од бока наниже, који служи за ходање, нога, доњи уд (лат. реs). Долнь части су нъкимъ видомъ свеза съ горныма утврђене, и на ньима се налазе многе мале коштице, кое ручне и ножне коричке сачиняваю, после коій онда прсти на рукама и ногама сльдую (ПМ 1844: 9).

ноздрва ж <ноздрва > један од два носна отвора (лат. nares). - Надъ овомъ кожомъ распрострети су нерви мирисаня, кои изъ мозга долазе, и крозъ коштицу на подобіе сита у ноздрве се спуштаю (ПМ 1844: 18).

нокат м <нокти> рожни покривач $y$ облику плочице на горњем крају прстију, на рукама и ногама (лат. unguis). - Она расти као и нокти на прстима, долньимъ частима горнъ протеруюћи (ПМ 1844: $10)$.

нос м <носъ> почетни, улазни део система за дисање између очију и уста, где је смештено и чуло мириса (лат. nanus). - $\underline{\text { Носъ}, ~ о р у д і е ~ о б о н я н і я, ~}$ (мирисаня) обложенъ е изъ нутра горе са сунђеру подобномъ шупльикастомъ кожомъ (ПМ 1844: 18).

\section{$\mathbf{O}$}

образ м <образима> једна страна лица (лат. gena). - Садъ се савія глава тако, да брада на прсима стои; [...] една рука, а често и обе леже на образима, или обе су поредъ тьла доле опружене (ПМ 1844: 4).

обрва ж <обрве> длаком обрасло дно чела, изнад очне дупље (лат. supercilia). - Надочна кожица (Augenlieder) чува ій одъ сваке опасности, и покрива ій при приближаваню ове; трепавице чуваю ій одъ прашине и наськомы, а обрве служе одъ части за украшеніе, а одъ части за удржавакь доле текућегъ зноя (ПМ 1844: 20).

око с <очи> орган чула вида код човека и животиња, смештен у очној дупљи (лат. oculus). - Тако су исто и очи художественне, кое намъ къ орудію вида служе (ПМ 1844: 20).

очна јабука ж <очна ябука> очна кугла коју творе бјелоочница и рожнача, очна јабучийа (лат. bulbus oculi). - Очна ябука е дугулясто округлый шаръ, кой се изъ разны кожа, и између ньи налазеће се влаге состои (ПМ 1844: 20).

очни зуб м <очни зуби> зуб између секутића и кутьака, очњак (лат. dentes canini). - Теме состои се изъ выше шупльи костію, кое су узубченымъ швомъ увезане; [...] сирьчь са свимъ спреда 8 секући зуба (горе и доле по четири), поредъ овы нас свакой страни горе и доле по еданъ очный или псећій зубъ, свега дакле четири и острагу 20 
кутньи зуба, на свакой страни горе и доле по 5 (ПМ 1844: 8).

очни нерв м <очны нерва> оптички живаи који је задужен за спајање ока са мозгом, (лат. n. орticu). - Прва е тврда или дебела теменна кожа, коя разнымъ наставцима или продуживаньма, оддъленія у мозгу чини, и осимъ теменяче такође и у кичму и около очны нерва као таблица (Scheide) распорстире се и пружа (ПМ 1844: 16).

очњак м <очняка> зуб између секутића и кутьљка (лат. dentes canini). - У седмомъ месецу, или и поздніе нышто, а често и при концу прве године, изиђу предньи зуби, ньи 7, а доциіе псећіи или очни, а съ концемъ прве године, или у другой кутняцы, поредъ свакогъ очняка 4 (ПМ 1844: 5).

\section{П}

пантљика од пупка <пантльике одь пупка> орган $у$ облику танке, цилиндричне врпце која спаја заметак у мајчиној утроби са телом мајке $u$ служи као канал за храну заметка, пупчаница, пупчана врпияа (лат. funiculus umbilicalis). - Препитаніе добива плодъ (embrio зачатіе) посредствомъ пантльике одь пупка (пуповину) крозь празднину материце (*) изъ крви матере (ПМ 1844: 4).

паучини подобна кожа ж <паучини подобна кожа> средња мождана овојница која обавија мозак и кичмену мождину, паучинаста мождана опна (лат. arachnoidea mater). - Друга паучини подобна кожа, лежи подъ ономъ, но нигди у удубляваня не допире (ПМ 1844: 16).

питателни сок м <питателный сокъ> продукт лучења многобројних жлезда слузокоже танког ирева који учествује у процесу варења хране, цревни сок. - У цревы се свариванъ ела, кое е стомакъ почео, продужава, питателный сокъ се последствомъ тамо налазећи се сосуда одъ ела оддвоява, а ђубре избацуе (ПМ 1844: 14).

плетиво нерва с <плетиво нерва> сплет више нерава, живчани сплет. - Кончићи нерва често се дъле, но опетъ се еданъ съ другимъ союжаваю, и образую дебело оддвоеніе или клупче нерва, кое се са основнымъ частима мозга прилично соглашаваю, и многе крвне сосуде содржаваю или се у замршеным свезама саставляю, кое се плетиво нерва зове [...] (ПМ 1844: 17).

плећа с мн. <плећа> горњи део леђа, између врата и руку. - Такође меснати листови, округли яки кукови, широка плећа, лепь вид главе, благородно изображеніе лица, на комъ уста нису као у маймуна губица изпубчена, горня устна съ малымъ танкимъ (на среди) каналићемъ, и друга свойства има само човеческо тьло (ПМ 1844: 1).

плећна кост ж <плећне кости> пљосната троугласта кост, приљубљена уз задюи део грудног коша, лопатийа (лат. scapula). - Горе надъ ребрыма леже обе плећне кости, и 
свезую се ключнымъ костима са пршномъ костћу (ПМ 1844: 9).

плећна ртењача $ж$ <плећне ртеняче> покретни вратни приљен који припада групи правих пршљенова, чији попречни пресек има отвор кроз који пролази кичмена артерија, вратни приљен (лат. vertabrae cervicales). - Главу држи и носи ртеняча, стубъ кой се изъ 24 поедины едно за другимъ движимы зглавкова состои, кои се на вратне ртеняче (плећне) и одъ кукова зглавкове дьле (ПМ 1844: 8).

плод м <плодъ> зачетак живог бића у мајичи, дете (лат. fetus). - После 1 месецъ дана быва плодъ одъ прилике еданъ цолъ дугачакъ, и мало накриво лежи у нъкой влаги између двђ кожице (ПМ 1844: 4).

плодно јајце с <плодномъ яйцету> оплођена јајна ћелија која настаје спајањем женског и мушког гамета, зигот (лат. zygotus). - Првый зачетакъ по свой прилицы лежи у плодномъ яйцету, кое крозъ каналчићь едан тако назван трумпета (Muttertrompete) у материцу уђе, и тамо се утврди (ПМ 1844: 3).

пљувачке сок м <плювачке сокъ> мешовити секрет три пара великих пљувачних жлезда: заушних, подвиличних и подјезичних, у устима човека која кваси и влажи храну која се једе (лат. saliva). - Црева су опеть на дебелой нъкой кожи, коя се марамица (Gekröse), зове, утврђена, коя се у двострукимъ листићима показуе, кои су масћу, жльздама, и сосудима напуньны, и гди се на подобіе плювачке сокъ одъ марамице (Gekrösesaft), оддвоява, кои се у прво црево излива, да смешавань мастны и водены частица у елыма подпомаже (ПМ 1844: 14).

попак м <попка> мала, округла удубина у кожи на средини трбуха, која настаје након пресецања пупчане врпце, пупак (лат. umbilicus). - У истој се виде мали союжени кончићи, изъ коій после седамъ дана дугулясто, готово провидно клупченце постане, одъ коега средине па до кожице нъки су кончићи пружени, кои су почетакъ цревета одъ попка (ПМ 1844: 4).

празнина материце ж <празднину материце> постељица у материци око заметка као веза између мајчине крви и ембриона, постељица, плацента (лат. placenta). - Препитаніе добива плодъ (embrio зачатіе) посредствомъ пантльике одь пупка (пуповину) крозь празднину материце (Mutterkuchen) изъ крви матере (ПМ 1844: 4).

празно црево с <праздно црево> покретни део танког ирева, који се састоји од 11-12 вијуга, јејунум. Друга црева зову се праздно црево, (Leerdarm), умотано црево, (Grimmdarm), слепо црево, (Blinddarm), криво црево, (Krummdarm), и дебелогузно-црево, (Mastdarm) (ПМ 1844: 14).

први мозак м <првый мозакъ> најразвијенији део цеентралног нервног система који се састоји од десне и леве хемисфере, изграђене од сиве и беле 
масе, велики мозак (лат. telencephalon). - Првый или великій мозакъ, лежи у свой горньой части темена - шупльине, и у долньой до половине (ПМ 1844: 16).

предворије с <преддворіе, преддворію> коштана шупљина у унутрашњем уху, трем (лат. vestibulum). - После добошне шупльине сльдуе лабиринть или извіенъ ходникъ, у коегъ средини се мала шупльина, преддворіе, а одь горе и сапреда се три на подобіе лука цевчице, кое се са петь улійва у преддворію отвараю, - а доле се на подобіе пужа увіенъ каналь налази (ПМ 1844: 20).

прилопак м <прилопке> део срияа чији је задатак да попут вентила усмеравају струју крви у одређеном правиу и спречавају юено враћање у супротном смеру, зализак (лат. valvula). - Крвне жиле доводе крвъ къ срцу, све се већма къ нъму разширую, и имаю по већой части прилопке, кои враћанъ напредъ отишавше крви предупређую (ПМ 1844: 11).

прозрачна кожа ж <прозрачна кожа> танак слој коже који шттти око од механичких и других повреда, својим покретима распоређује сузе и осигурава влажење рожначе, очни капак (лат. palpebrae). - Међу овимъ листовыма содржава се бистрый сокъ и цЊло тьло обкружава нъжна прозрачна кожа, као заклопаць (ПМ 1844: 21).

прозрачни лист м <прозрачны листова> фина влакна ока која повезују цилијално тело и сочиво, цилијарна зонула (лат. zonula ciliaris). - Но иза дужне коже међу двема влагама (тако зововымъ воденомъ и оном' другомъ на подобіе стакла) лежи кристално сочиво овога на объма странама узвышено тъло, кое се изъ више прозрачны листова состои (ПМ 1844: 21).

прса с мн. <прсію> предюи део тела од врата до трбуха, груди (лат. thorax). Положеніе срца ніе усправно, и ніе у среди прсію, него лежи косо, съ тупльимь краемъ къ львой, а съ широмъ часћу къ десной страни, а острагъ къ кичми окренуто (ПМ 1844: 11).

прст м <прсти> један од пет покретних крајюих делова руке или ноге човека (лаm.digitus). - Долнь части су нькимъ видомъ свеза съ горныма утврђене, и на ньима се налазе многе мале коштице, кое ручне и ножне коричке сачиняваю, после коій онда прсти на рукама и ногама сльдую (ПМ 1844: 9).

пршна кост <пршномь костћу> пљосната грудна кост, надгрудница (лат. episterum). - На 12 ртенячнымъ зглавковима, кои после 7 вратны зглавкова сльдую, на свакой су страни толико ребара привезаны, одъ коій се горньи 7 у малый кругъ савіяю и са пршномъ костћу са нЊкомъ рскавицомъ свезую (ПМ 1844: 8).

пршна шупљина ж <пршна шупльина> дупьа смештена изнад, односно испред трбушне иупьине, а заштићена ребрима, грудна дупља. - Пршна шупльина одъ долньгъ трбуха оддълена е лажичицомъ, коя е на прсима 
узвышена, а у нутри у долньмъ трбуху шупля (ПМ 1844: 15).

пршни ход м <пршный ходъ> осовински, коштани стуб изграђен од приљенова, који чини основу читавог скелета, кичмени стуб (лат. columna verberalis). - Млечна кеса излива сокъ препитанія у пршный ходъ, танакъ еданъ каналъ, кой по кичми горе у высину иде, и кои се даль и на львой страни, из'а велике біюће жиле, у крвну жилу на львой ключной кости одводи (ПМ 1844: 15).

псећи зуб м <псећій зуб> зуб између секутића и кутьака, очьак (лат. dentes canini). - Теме состои се изъ выше шупльи костію, кое су узубченымъ швомъ увезане; [...] сирьчь са свимъ спреда 8 секући зуба (горе и доле по четири), поредъ овы нас свакой страни горе и доле по еданъ очный или псећій зубъ, свега дакле четири и острагу 20 кутньи зуба, на свакой страни горе и доле по 5 (ПМ 1844: 8).

пуж м <пужа> предњи део коштаног лавиринта уха, који има облик кућице пужа (лат. cochlea). - После добошне шупльине сльдуе лабиринть или извіенъ ходникъ, у коегъ средини се мала шупльина, преддворіе, а одъ горе и сапреда се три на подобіе лука цевчице, кое се са петъ улійва у преддворію отвараю, - а доле се на подобіе пужа увіенъ каналъ налази (ПМ 1844: 20).

пуповина ж <пуповину> орган у облику танке, иилиндричне врпце која спаја заметак у мајчиној утроби са телом мајке и служи као канал за храну заметка, пупчаница, пупчана врпца, (лam. funiculus umbilicalis). - Препитаніе добива плодъ (embrio зачатіе) посредствомъ пантльике одь пупка (пуповину) крозь празднину материце (Mutterkuchen) изъ крви матере (ПМ 1844: 4).

\section{$\mathbf{P}$}

раме с <раме> део тела између врата и надлактице. - Руке уметнуте су са горньимъ своимъ частима у нъкимъ шупльинама плећны костію, и имаю три части: paмe, мишицу, горню предню мишицу, и руку... (ПМ 1844: 9).

ребро с <ребра > једна од дванаест пари танких и извијених костију, везаних за кичму, које обавијају грудни кош (лат. costa). - Трупу принадлеже ребра, кичма, и трбухъ (Becken), са осталымъ составнымъ частима внутреины (црева); къ удовима пакъ плећа, мишице, руке, голени, и ноге (ПМ 1844: 7).

ресица ж <ресица> продужетак задњег краја меког непия у ждрелу у облику меснатог, покретног језичка (лат. uvula). - Найзнаменитіе орудіе говореня есть ресица, съ воздушноцЊвнимъ чворомъ у гркляну, кой е шупля, изъ више рскавица состоећа се цЊвь, и кой се доле у воздушной цъви (грлу) отвара (ПМ 1844: 13).

рожна кожа ж <рожна кожа> предњи, провидни и испупчени део спољашње опне очне јабучице, рожнача (лат. cornea). - Очну ябуку обкружава с' поля 
рожна кожа, продуженіе тврде темене коже (ПМ 1844: 20).

рскавица ж <р'скавица> врста чвршћег везивног ткива, око костију или уместо њих, у телу кичмењака (лат. cartilago).

- Уво е съ поля дугулясто увіена, на нъки мъсты угнута р'скавица, да бы се звукъ лакше пріимити, и у ходникъ чувеня одпратити мог'о (ПМ 1844: 19).

рскарица ж <рскарицама $>$ врста чврићег везивног ткива, око костију или уместо њих, у телу кичмењака (лат. cartilago). - Има ій преко полтреће стотине, кое су све рскарицама и мушкулама свезане, и несматраюћи на ову свезу, одъ части поедине, одъ части у союзу съ другима, по вольи и сили, коя ій управля, могу опредьлена своя дъла извршивати (ПМ 1844: 8).

ртењача ж <ртеняча> осовина скелета човека и неких животиња који се протеже дуж леђа и састављен је од кичмених приљенова, кичма (лат. columna verberalis). - Главу држи и носи ртеняча, стубъ кой се изъ 24 поедины едно за другимъ движимы зглавкова состои...(ПМ 1844: 8).

ртењачки зглавак <ртенячнымь зглавковима> грудни пршљен који припада групи од 12 правих пршљенова (лат. vertebrae thoracicae). - На 12 ртенячнымъ зглавковима, кои после 7 вратны зглавкова сльдую, на свакой су страни толико ребара привезаны, одъ коій се горньи 7 у малый кругъ савіяю и са пршномъ костћу са нькомъ рскавицомъ свезую (ПМ 1844: 8). рука ж <руке, руку> један од горњих удова човечјег тела, екстремитета од рамена до врхова прстију (лат. агтиs). - Руке уметнуте су са горньимъ своимъ частима у нъкимъ шупльинама плећны костію, и имаю три части: раме, мишицу, горню предню мишицу, и руку... (ПМ 1844: 9).

ручна коричка ж <ручне коричке> један од горњих екстремитета човечјег тела, од рамена до врхова прстију, рука, горюи уд (лат. armus). - Долнь части су нъкимъ видомъ свеза съ горныма утврђене, и на ньима се налазе многе мале коштице, кое ручне и ножне коричке сачиняваю, после коій онда прсти на рукама и ногама сльдую (ПМ 1844: 9).

\section{C}

сало с <сало> > масне наслаге у телу човека и неких животиња, маст (лат. unguen). - Подъ кожомъ и међу разнымъ частима животиня лежи масть (ало, дебльина), као у кончаномъ плетиву... (ПМ 1844: 10).

сасуд м <сасуда> крвни суд, чија је функиија преношење крви кроз тело (лат. vas).. - Она, коя е са свымъ унутри, зове се убрани кожа (Samthaut) - и има множество испараваюћи и усисаваюћи сасуда у виду фины кончића и брадавица (ПМ 1844: 13).

секући зуб м <секући зуби> предњи зуб пљоснотог облика у горњој и доњој вилици (по четири зуба), којима се храна сече, гризе, секутић (лат. dentes incisivi). 
- У седмомъ месецу, или и поздніе нђшто, а често и при концу прве године, изиђу предньи секући зуби, ньи 7, а доциіе псећіи или очни, а съ концемъ прве године, или у другой кутняцы, поредъ свакогъ очняка 4 (ПМ 1844: 5).

слезина ж <слезина> велика жлезда $y$ трбушној иупљини с леве стране, испод дијафрагме и задњих ребара, а главна функиија јој је стварање ирвених крвних зрнаца (лат. lien). - Слезина, дугулястоокругло, горе узвіено тьло, лежи на десной страни према црной џигерицы, и есть шупльикастогъ вида, а изгледа плаветно-црвеногъ (ПМ 1844: 15).

слепо око с <сльпи очію> бочни део логање од уха до чеоне кости, слепоочница (лат. tетрога). - Теме состои се изъ выше шупльи костію, кое су узубченымъ швомъ увезане; а къ овыма принадлеже такође кости сльпи очію, носъ, небце, и вилице... (ПМ 1844: $8)$.

слепо црево с <слепо црево> почетни, најшири део дебелог ирева са ирвуљком (лат. саесит). - Друга црева зову се праздно црево, (Leerdarm), умотано црево, (Grimmdarm), слепо црево, (Blinddarm), криво црево, (Krummdarm), и дебело-гузно-црево, (Mastdarm) (ПМ 1844: 14).

сок препитанија м <сокъ препитанія> лимфа пробавног система која у себи садржи капљице масти, хилус (лат. hilum). - Млечна кеса излива сокъ препитанія у пршный ходъ, танакъ еданъ каналъ, кой по кичми горе у высину иде, и кои се даль и на львой страни, из'а велике біюће жиле, у крвну жилу на львой ключной кости одводи (ПМ 1844: 15).

сосуд м <сосуда, сосудима $>$ крвни суд (лат. vas). - Она е жльзди подобный дробъ, и изъ неброены сосуда саставльна, одъ коій су найзнаменитіе вратарна жила (Pfortader, нька крвна жила) црно џигерична біюћа жила, и онда жучъ са своимъ сосудима (ПМ 1844: 14).

сочиво с <сочиву> део ока кроз који се светлост прелама пре него што падне на мрежначу (лат. lens). - Една се зове чекичъ, кой е посредствомъ нЊкогъ држка са добошномъ кожомъ свезанъ; друга коштица се зове наковань, кой се съ главомъ чекича свезуе, између потеге наковня и треће коштице, на подобіе узенгие, лежи сочиву-подобна коштица, найманя кость у цовечіемъ тьлу (ПМ 1844: 19).

срце с <срца> иупљи мишићни орган чија је унутрашњост једном уздужном преградом подељена на две половине, десну и леву, које се састоје од преткоморе и коморе (лат. сог). - Срце e великій шупльій мушкулъ, кой е густимъ еднымъ зидомъ на две срчане камерице подълено, и узрокъ е, кой двеженіе и околотеченъ течностій у тьлу оддржава (ПМ 1844: 11).

срчана камерица ж < срчане каменице> срчана шупљина, срчана комора, клетка (лат. ventriculus cordis). - Срце е великій шупльій мушкулъ, кой е 
густимъ еднымъ зидомъ на две срчане камерице подълено, и узрокъ е, кой двеженіе и околотеченъ течностій у тълу оддржава (ПМ 1844: 11).

срчана кеса ж <срчана кеса> опна која обавија срие, састоји се из спољашьег дела, изграђеног од везивног ткива и унутрашњег дела од посебног везивног ткива и два листа (лат. pericardium). Срце е у дебелой едной кожи, као са кесомъ обмотано, коя се срчана кеса и зове (ПМ 1844: 11).

срчано уво с <срчане уши> део сриа на спољашњем зиду десне и леве срчане коморе, увасти наставак. - Надъ срчанимъ камерама леже тако назване срчане уши, кое никаквогъ взаимногъ дъйствованя не'маю, него свако за себе са своіомъ срчаномъ камеромъ (ПМ 1844: 11).

стомак м <стомакъ> орган за варене, смештен у горњем делу трбушне дупље, трбух (лат. abdomen). - Прво орудіе препитаніа есть стомакъ, дугуластоокругла кесса горе у шупльини трбуха на левой страни, коя съ гркляномъ, съ цевлю за ело, и са цревма едно цъло сочинява (ПМ 1844: 13).

судић м <судићи> мањи шупљи орган у човечјем телу са различитим функцијама. - Съ поля пуна е малы брадавица, у коима се краеви кожны нерва, орудія осећаня и судићи за непримътително изпареніе окончаваю (ПМ 1844: 9).
$\mathbf{T}$

тајни удови тела м <тайне удове тьла> мушки или женски полни органи, гениталије (лат. genitalua). Они къ тому служе, да мокраћу изъ крви оддълюю, коя се крозъ кожне канале у мокраћну бешику излива, одъ куда она крозъ свое канале (Harnröhre) у тайне удове тьла одлази, и избацуе се (ПМ 1844: 15).

танка темена кожа ж <танка темена кожа> унутрашња мождана овојница која обавија мозак и кичмену мождину, мека мождана опна (лат. pla mater). Трећа е танка темена кожа, плетиво одъ найфаиніи крвны и біюћи жила гранчица, коя у све боре мозга улази, и споляшна продуженія нъгова, као и нерве спроводи (ПМ 1844: 16).

танко црево $\mathrm{c}<$ танкогъ цревета $>$ део система за варење који се пружа од пилоричног отвора желуцуа до почетног дела дебелог и слепог ирева (лат. intestinum tenue). - Почетакъ танкогъ цревета, одъ стомака одма рачунаюћи, зове се 12-прстно црево (Zwölffingerdarm), ербо е одъ прилике 12 прста широко, и 12 цолова дугачко (ПМ 1844: 14).

тврда темена кожа ж <тврда теменна кожа> спољашьа мождана овојница која обавија мозак и кичмену мождину, тврда мождана опна (лат. duru mater). - Прва е тврда или дебела теменна кожа, коя разнымъ наставцима или продуживаньма, оддъленія у мозгу чини, и осимъ теменяче такође и у кичму и около очны нерва као таблица 
(Scheide) распорстире се и пружа (ПМ 1844: 16).

теме с <темену> врх главе, лобање (лат. vertex). - Теме состои се изъ выше шупльи костію, кое су узубченымъ швомъ увезане... (ПМ 1844: 8).

темењача ж <темењача> парна пљосната испупчена кост, четвртастог облика која гради кроз лобање, темена кост (лат. os parietale).

- Темењача (кость на темену) е горе мало отворена тако, да се біенъ жиле у мозгу осетити може (ПМ 1844: 4).

трбух м <трбухъ> део тела у коме су желудаи и ирева; испупчени део тела и унутрашњи простор са органима који cy y юему (лат. abdomen). - Трупу принадлеже ребра, кичма, и трбухъ (Becken), са осталымъ составнымъ частима внутреины (црева); къ удовима пакъ плећа, мишице, руке, голени, и ноге (ПМ 1844: 7).

трепавица ж <трепавице> длаке на ивиции очних капака (лат. cilia). Надочна кожица (Augenlieder) чува ій одъ сваке опасности, и покрива ій при приближаваню ове; трепавице чуваю ій одъ прашине и наськомы, а обрве служе одъ части за украшеніе, а одъ части за удржавакъ доле текућегь зноя (ПМ 1844: 20).

тромпета ж <тромпета> коштаноопнасто-хрскавичава цев која спаја бубну дупљу и носни део ждрела, слушна труба (лат. tuba auditiva). Ондь, гдъ изъ добошне шупльине излази, потврдъ е као кость и узанъ, а напредъ къ носу р'скавъ и поширокъ; збогъ оваквогъ свогъ вида зове се тромпета (ПМ 1844: 19).

трумпета ж <трумпета> слузокожни канал чија је функиија да прихвати јајну ћелију и спроведе је до материце, јајовод (лат. tuba uterina). - Првый зачетакъ по свой прилицы лежи у плодномъ яйцету, кое крозъ каналчићь едан тако назван трумпета (Muttertrompete) у материцу уђе, и тамо се утврди (ПМ 1844: 3).

труп м <трупъ> средишьи, иентрални део човечјег или животињског тела, између врата и удова, који обухвата грудни кош, трбух и карлииу (лат. truncus). - Човеческо тьло дђли се на главу, трупъ, и удове (ПМ 1844: 7).

\section{$\mathbf{h}$}

Һушка ж <ћушке> задюи део главе. Трећа часть зове се дугулястый мозакъ, и состои се изъ свезе мозганы фибра великогъ и малогъ мозга, лежи на кости заднъ части главе (ушке), и продужуе ce, почемъ крозъ шупльину ове, у шуплину зглавкова кичмены иде, у кичмену масть (мозакь) (ПМ 1844: 16).

\section{$\mathbf{y}$}

убрани кожа ж <убрани кожа> дубоки везивни слој коже, у којем су смештени капилари и живци коже, длаке, знојне и лојне жлезде и глатке мишићне ћелије које су везане за корен длаке, крзно (лат. dermis). - Она, коя е са свымъ унутри, зове се убрани кожа (Samthaut) - и има 
множество испараваюћи и усисаваюћи сасуда у виду фины кончића и брадавица (ПМ 1844: 13).

уво с <уво> орган чула слуха $и$

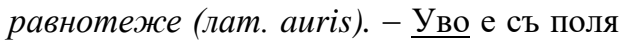
дугулясто увіена, на нъки мъсты угнута р'скавица, да бы се звукъ лакше пріимити, и у ходникъ чувеня одпратити мог'о (ПМ 1844: 19).

уд м <удови> заједнички назив за руке и ноге као органе кретања. - Садъ сльдую удови, кои се на горнъ и долнь, или на руке и ноге дъле (ПМ 1844: 9).

ударајућа жила <удараюће жиле> жила којом тече крв из сриа у све делове тела, артерија. - Изъ срца крозъ жиле двоякогъ рода, крвъ се крозъ цБло тьло истеруе, сирьчъ крозъ біюће или удараюће жиле (Schlagader), и кроз крвне жиле (ПМ 1844: 11).

узенгија ж <узенгие> слушна кошчица у средњем уху, стремен (лат. stapes). Една се зове чекичъ, кой е посредствомъ нЊкогъ држка са добошномъ кожомъ свезанъ; друга коштица се зове наковань, кой се съ главомъ чекича свезуе, између потеге наковня и треће коштице, на подобіе узенгие, лежи сочиву-подобна коштица, найманя кость у човечіемъ тьлу (ПМ 1844: 19).

умотано црево с <умотано црево> део дебелог ирева који се наставља на слепо црево, а на юему се разликују четири дела: усходни, попречни, нисходни и сигмоидни, сито црево, (лат. colon). Друга црева зову се праздно црево,
(Leerdarm),

умотано црево, (Grimmdarm), слепо црево, (Blinddarm), криво црево, (Krummdarm), и дебелогузно-црево, (Mastdarm) (ПМ 1844: 14).

уста с <уста> иупљина у доњем делу са унутрашье стране зубне преграде, као почетни орган за варење кроз који пролази храна у желудаи (лат. stoma). Такође меснати листови, округли яки кукови, широка плећа, лепъ вид главе, благородно изображеніе лица, на комъ уста нису као у маймуна губица изпубчена, горня устна съ малымъ танкимъ (на среди) каналићемъ, и друга свойства има само човеческо тьло (ПМ 1844: 1).

усна ж <устна> једна од две меснате покретне ивице које споља заклањају зубе (лат. labia). - Такође меснати листови, округли яки кукови, широка плећа, лепъ вид главе, благородно изображеніе лица, на комъ уста нису као у маймуна губица изпубчена, горня устна съ малымъ танкимъ (на среди) каналићемъ, и друга свойства има само човеческо тьло (ПМ 1844: 1).

\section{$\Phi$}

фалично ребро с <фалична ребра > > најкраће, највиче закривљено ребро и спљоштено одозго надоле, прво ребро (лат. costa prima). - На 12 ртенячнымъ зглавковима, кои после 7 вратны зглавкова сльдую, на свакой су страни толико ребара привезаны, одъ коій се горньи 7 у малый кругъ савіяю и са пршномъ костћу са нъкомъ рскавицомъ 
свезую; а друга су 5 кратка или фалична ребра (ПМ 1844: 9)

фибра ж <фибра> мишићно влакно, жилица, кончић (лат. fibra). - У ньима cе содржаваю (животиня) фибре съ нервыма и кончанымъ плетивомъ, крвнымъ и воденымъ судићима уплетене, и нъкимъ видомъ лепа (туткала) къ цЂлому едномъ союжене (ПМ 1844: 10).

\section{$\mathbf{X}$}

ходник м <ходникъ > део увета грађен у спољашњој трећини од хрскавице, а осталом делу од кости, у чијој се кожи налазе лојне и велике знојне жлезде које стварају ушну маст, спољашьи ушни ходник (лат. meatus acusticus externus). У овомъ има много жльздій, кое горку нъку влагу оддълюю, чрезъ што се ходникъ углађава, и мекшій задржава, а прашини или малымъ наськомымъ улазакъ препречава (ПМ 1844: 19).

ходник чувења м < ходникъ чувеня> ушни канал (лат. meatus acusticus externus). Уво е съ поля дугулясто увіена, на нъки мъсты угнута р'скавица, да бы се звукъ лакше пріимити, и у ходникъ чувеня одпратити мог'о (ПМ 1844: 19).

\section{Ц}

цев за јело <цЊвъ за ело> слузокожномишићни орган, олучастог облика, који се пружа од базе лобане наниже, изнад гркљана и једњака и представља раскрснииу система за дисање $u$ система за варење, ждрело (лат. pharynx). - Грло е на подобіе левка каналъ, и есть продуженіе внутрень коже уста; ондъ гдъ е на подобіе валька, починъ се звати цҺвъ за ело, (Speiseröhre) (ПМ 1844: 13).

цевчица ж <цевчице> ушни канал који се увија спирално око стожера, образујући две и по вијуге, коштани канал (лат. canalis spiralis cochleae). После добошне шупльине сльдуе лабиринтъ или извіенъ ходникъ, у коегъ средини се мала шупльина, преддворіе, а одъ горе и сапреда се три на подобіе лука цевчице, кое се са петь улійва у преддворію отвараю, - а доле се на подобіе пужа увіенъ каналь налази (ПМ 1844: 20).

црево с <цревы> део органа за варење у облику меке и растегљиве цеви $у$ људском телу (лат. intestinum). - $\mathrm{y}$ цревы се свариванъ ела, кое е стомакъ почео, продужава, питателный сокъ се последствомъ тамо налазећи се сосуда одъ ела оддвоява, а ђубре избацуе (ПМ 1844: 14).

црна џигерица ж <црна џигерица> жлезда јајастог облика код човека или животиња која излучује жуч и врши низ најважнијих процеса који су у вези са разменом материја у организму, јетра (лат. hераг). - Црна џигерица, найвеће внутреннъ (црево), долньгъ трбуха, лежи на десной страни подъ краткимъ ребрима (ПМ 1844: 14).

црноџигерична бијућа жила ж <црно џигерична біюћа жила> вена иза главе панкреаса, која настаје спајањем горње 
цревне вене и слезинске вене, чије стабло долази до улазних врата јетре и рачва се на своје две заврине гране, десну и леву, вена порте (лат. vепа portae hepatis). - Она е жльзди подобный дробъ, и изъ неброены сосуда саставльна, одъ коій су найзнаменитіе вратарна жила (Pfortader, нъка крвна жила) црно џигерична біюћа жила, и онда жучъ са своимъ сосудима (ПМ 1844: 14).

\section{$\mathbf{4}$}

чекич м <чекичъ> једна од слушних кошчица, чекић (лат. malleus). - Една се зове чекичъ, кой е посредствомъ нЊкогъ држка са добошномъ кожомъ свезанъ; друга коштица се зове наковань, кой се съ главомъ чекича свезуе, између потеге наковня и треће коштице, на подобіе узенгие, лежи сочиву-подобна коштица, найманя кость у човечіемъ тьлу (ПМ 1844: 19).

\section{Џ}

џигерица ж <џигерица> главни део система органа за дисање, у којем се врии размена гасова, бела цигерица, плућа (лат. pulmones). - Увлаченьмъ и изпуштавђмъ воздуха, џигерица се на объма странама и разшируе и скупля, а чрезъ то се и крвни сосуди часъ стешнюю, а часомъ разширую (ПМ 1844: 15).

џигерна бијућа жила ж <џигерна біюћа жила> једна од четири вене која преноси артеријску крв из плућа у леву срчану преткомору, плућна вена (лат. vепае pulmonale). - Одъ обои има двояка главна стабла; едно се разширива све то съ маньимъ гранчицама крозъ сво тьло, и ово е џигерна біюћа жила, коя изъ десне срчане камере произлази, и крвъ у белу џиферицу и т. д. носи, - ца е онда велика біюћа жила, коя изъ леве срчане камере, у све части тьла иде... (ПМ 1844: 11).

\section{III}

шиљаста кост ж <шилясте кости> савијена кост у доњем крају кичме која настаје срастањем четири до пет тртичних закржљьлих приљенова, тртична кост (лат. os coccygis). Шиляста (као репъ, Schwanzbein) костъ есть такова, коя до дебелогъ цревета допире, и коя е на вр'у унутра привіена (ПМ 1844: 9).

шупља жила ж >шупля жила> вена која враћа венску крв из горне половине тела, а настаје спајанем десне и леве брахиочефаличне вене, горьа иупља жила vепа (лат. саva superior). - Одъ обои има двояка главна стабла; едно се разширива све то съ маньимъ гранчицама крозъ сво тьло, и ово е џигерна біюћа жила, [...] у другом стаблу подразумъваю се двь главне крвне жиле, сирьчь, шупля жила (Hohlader) коя изъ свію частій тьла скупльну крвъ у десно срчано уво уноси, одкудъ се она у десну срчану камеру, и одатле крозъ бълоџигерну біюћу жилу одводи - и крвна жила, коя крвъ у льво срчано уво уноси, изъ коегъ у леву срчану камеру улази, да одатле 
теченіе свое на ново почне (ПМ 1844: 11).

\section{шупљина зглавка кичменог ж} <шуплину зглавкова кичмены> отвор који се налази у сваком пршьену градећи кичмени канал у којем је смештена кичмена мождина, пршьенски отвор (лат. foramen vertebrale). - Трећа часть зове се дугулястый мозакъ, и состои се изъ свезе мозганы фибра великогъ и малогъ мозга, лежи на кости заднъ части главе (ћушке), и продужуе се, почемъ крозъ шупльину ове, у шуплину зглавкова кичмены иде, у кичмену масть (мозакь) (ПМ 1844: 16).

шупљина носа <шупльина носа> почетни, прочирени део дисајних путева, смештен у предњем делу средишьег предела главе, а носном преградом подељен је на две симетричне половине, које се напред отварају ноздрвама (лат. cavitas nasi). Шупльина носа састае се острагу са шупльиномъ уста; отудъ здравъ носъ врло много приноси къ чистомъ изговараню (ПМ 1844: 19).

шупљина ока ж <шупльину очиу> коштане шупьине, смештене с обе стране корена носа, у чијој унутрашьости су смештене очи (лат. orbita). - Живацъ виђеня овай дебео е одъ прилике као гушчіе перо, и изъ мозга у очну ябуку улази крозъ шупльину очиу (ПМ 1844: 21).

шупљина трбуха ж <шупльина трбуха> простор унутар трупа који се налази испод пречаге, трбушна дупља (лат. cavitas abdominalis). - Шупльина трбуха обучена е кожицомъ одъ црева... (ПМ 1844: 15).

шупљина уста ж <шупльиномъ уста> почетни, прочирени део органа за варење, усна дупьь (лат. cavitas oris). Шупльина носа састае се острагу са шупльиномъ уста; отудъ здравъ носъ врло много приноси къ чистомъ изговараню (ПМ 1844: 19).

\section{5. Закључак}

Анализом анатомске терминологије у делу Кратко сочињеније антропологије или Наука о човеку Петра Радовановића (1844), долази се до закључка да се терминолошки систем из области анатомије у великој мери изменио у односу на савремени. Такво стање је и очекивано јер је дело писано током прве половине 19. века, дакле, у предстандардном периоду. ${ }^{1}$

\footnotetext{
${ }^{1}$ Да би се извршило поређење грађе с анатомском терминологијом у стандардном српском језику, коришћен је уџбеник за средњу медицинску школу Анатомија и физиологија (Anđelković i dr. 2002) ${ }^{1}$, уџбеник који је намењен студентима Факултета
} 
Ако се посматра порекло терминолошких јединица, уочава се да је убедљиво највећи број термина домаћег порекла, што говори о високом нивоу терминологизације лексема општег лексичког фонда. ${ }^{2}$ Број термина страног порекла је веома мали. Уколико се и употребљавао неки страни термин, то је најчешће у вишечланим терминолошким јединицама где је само једна лексема страног порекла.

Добијена грађа рефлектује стање у овом пољу терминологије током прве половине 19. века, а будућа истраживања, спроведена на ширем корпусу, пружиће нам јаснију слику о процесима и даљем развоју овог сегмента лексикона.

\section{ИЗ В О Р}

Радовановић, Петар (1844). Кратко сочињеније антропологије или Наука о човеку. Београд: Књигопечатња Књажества Србског.

\section{ЛИТ Е Р А Т У Р А}

Бјелаковић, Исидора (2017). Терминологија код Срба у 18. и 19. веку (математичка географија и картографија). Нови Сад: Два пера.

Винавер, Н. (1996). О терминологији: између праксе и теорије. Стандардизащија терминологије. Београд: Српска академија наука и уметности. 21-24.

Вујаклија, Милан (1996/97). Лексикон страних речи и израза. Београд: Просвета.

Гортан-Премк, Даринка (1991). О терминолошким јединицама и юиховој обради у Речнику САНУ. Наш језик. Београд. ХXIX/1-2: 49-54.

Драгићевић, Рајна (2007). Лексикологија српског језика. Београд: Завод за уџбенике. Клајн, Иван и Милан Шипка (2008). Велики речник страних речи и израза. Нови Сад: Прометеј.

Пешикан, Митар, Јован Јерковић и Мато Пижурица (2010). Правопис српског језика. Нови Сад: Матица српска.

спорта и физичког васпитања Анатомија човека (Obradović i dr. 2006), Енциклопедијски лексикон - Мозаик знања: Биологија (Јанковић $1973^{1}$ ) и Višejezički medicinski rečnik (Kostić 2009).

2 Порекло је анализирано на основу Речника српскохрватског књижевног језика (1990), Лексикона страних речи и израза Милана Вујаклије (1996/97), Великог речника страних речи и израза (Клајн и Шипка 2008), Etimologijskog rječnika hrvatskoga ili srpskoga jezika Петра Скока (Skok 1971-1974) и Rječnika hrvatskoga ili srpskog jezika JAZU (1880-1976). 
РСАНУ: Речник српскохрватског књижевног и народног језика, I-XXI. Београд: Институт за српски језик САНУ, 1959-.

PMC: Речник српскохрватског књижевног језика, I-VI. Нови Сад - Загреб: Матица српска - Матица хрватска, 1990.

Суботић, Љиљана (2004). Из историје књижевног језика: „питање језика”. Предавања из историје језика. Нови Сад: Филозофски факултет. 145-191.

Anđelković, Ivan, Aleksandar Stajkovac i Aleksandar Ilić (2002). Anatomija i fiziologija. Beograd: Zavod za udžbenike i nastavna sredstva.

Kostić, Aleksandar Đ. (2009). Višejezički medicinski rečnik. Beograd: Jasen.

[Milorad Janković] (1973). Enciklopedijski leksikon - mozaik znanja. T. 19: Biologija. Beograd: Interpres. (M3-Б).

RJAZU: Rječnik hrvatskoga ili srpskog jezika, I-XXIII. Zagreb: JAZU, 1880-1976.

Obradović, Dušica, Marija Mihalj i Borislav Obradović (2006). Anatomija čoveka. Novi Sad - Sremska Mitrovica: Udruženje kulturnih stvaralaca Srbije „Zavičaj”.

Skok, Petar (1971-1974). Etimologijski rječnik hrvatskoga ili srpskoga jezika. 1-4. Zagreb.

Šipka, Danko (1998). Osnovi leksikologije i srodnih disciplina. Novi Sad: Matica srpska. 
Jovana Jović

LEXICOGRAPHIC PROCESSING OF ANATOMICAL TERMINOLOGY IN КРАТКО СОЧИҢЕНИЈЕ АНТРОПОЛОГИЈЕ ИЛИ НАУКА О ЧОВЕКУ ВУ PETAR RADOVANOVIĆ (1844)

\section{SUMMARY}

The paper analyzes the terminological system of the pre-standard epoch of the Serbian literary language development from the anatomy domain recorded in the work Кратко сочињеније антропологије или Наука о човеку by Petar Radovanović (1844). Beside information about author, terminology, theoretical and methodological frameworks of the research, the excerpted material is presented in a dictionary form and divided into semantic fields. This research was written in order to determine the relation between analyzed anatomical terminology and corresponding register of the contemporary Serbian language and to determine the reasons for losing one or keeping other terms.

KEYWORDS: terminological system, terminology, anatomy, 19th century.

Мср Јована Јовић

Одсек за српски језик и лингвистику Филозофски факултет, Универзитет у Новом Саду Србија jovana080895@hotmail.com 
